\title{
FURTHER INFORMATION ON ECTOMYCORRHIZAL MACROFUngI IN THE GREATER Yellowstone AREA
}

\author{
JOE F. AMMIRATI $\downarrow$ M. T. SEIDL $\downarrow$ P. B. MATHENY \\ DEPARTMENT OF BOTANY UNIVERSITY OF WASHINGTON \\ SEATTLE \\ MEINHARD MOSER \\ LEOPOLD-FRANZENS-UNIVERSITÄT INNSBRUCK \\ INSTITUT FÜR MIKROBIOLOGIE (N. F.) \\ INNSBRUCK $\downarrow$ AUSTRIA \\ BRADLEY R. KROPP $\downarrow$ BIOLOGY DEPARTMENT \\ UTAH STATE UNIVERSITY $\downarrow$ LOGAN
}

\begin{abstract}
Mushroom collecting in the Greater Yellowstone Area was relatively poor during the summer of 1999 due to a cool early season followed by dry weather during the summer. It was perhaps the poorest year of a long term study of Cortinarius, which Meinhard Moser and the late Vera and Kent McKnight began in earnest in the early 1980s; later joined by Joe Ammirati. None-the-less during the season Meinhard Moser was able to paint more than forty-five species for the monograph we are preparing on the Cortinarii of this region. At the end of the season, in late August, some good collections of Cortinarii were made at Sandpoint on Yellowstone Lake, and Lilypad Lake in Yellowstone National Park.
\end{abstract}

In 1999 we collected in Grand Teton National Park (Taggart Lake, Steamboat Mountain, Reid Mountain, Berol Lodge), Rockefeller Memorial Parkway (Grassy Lake), and Yellowstone National Park (Lewis Lake, Sandpoint on Yellowstone Lake, Lilypad Lake) as well as Bridger-Teton National Forest (Two Oceans Mountain, Lost Lake, Turpin Meadow, Fourmile Meadow, Flagstaff Road,
Togwotee Lodge) and Shoshone National Forest (Deception Creek, Togwotee Pass, Brooks Lake, Wind River Spring).

By comparison, the 1997 season was moderately good in some areas but poor in others. None-the-less we found some interesting Cortinarii in 1997 including several new species, Cortinarius citriolens Ammirati \& Moser, C. calojanthinus Moser \& Ammirati, C. pseudovariegatus Moser, C. variosimilis Moser \& Ammirati, $C$. infractus var. flavus Moser, and C. sannio Moser, and several new records including C. superbus A. H. Smith (see Moser and Ammirati, 1999). Over the years, many Cortinarii have been collected that will be the subject of several papers in the near future. One of us, Michelle Seidl (2000) published on phylogenetic relationships in Cortinarius, subgenus Myxacium, which includes a number of taxa collected in the Greater Yellowstone Area in previous years.

In 1999 two of us, Brandon Matheny and Bradley Kropp, especially collected species of Inocybe, a common ectomycorrhizal genus found 
throughout the Rocky Mountains and elsewhere. A number of Inocybes were collected and identified from the region, with several collections still to be determined to species. Those identified to date include Inocybe agardhii (Lund) Orton, I. dulcamara (Pers.) Kumm., I. flavella P. Karsten, I. geophylla (Sow.:Fr.) Kumm. var. geophylla, I. geophylla var. lilacina (Peck) Gillet I. jacobi Kühner (Illustrated), I. lacera (Fr.:Fr.) Kumm var. lacera, I. lacera var. rachodes (J. Favre) Kuyp., I. lanuginosa (Bull.:Fr.) Kumm., I. leiocephala Stuntz, I. leptophylla Atk., I. leucoblema Kühner (Illustrated), I mytiliodora Stangl \& Vauras (Illustrated), recently described from Europe and a first report of this species from North America, I. nitidiuscula (Britz.) Sacc., I. obscurobadia (J. Favre) Grund \& Stuntz, I. rimosa (Bull.:Fr.) Kumm., I. subcarpta Bours. \& Kühner (Illustrated), and I. terrigena (Fr.) Kuyp. Some of these taxa are reported on in a paper by Mathney and Kropp (2001).

\section{ACKNOWLEDGMENTS}

We would like to acknowledge the assistance of Hank Harlow, Director of the University of Wyoming and National Park Service Research Center and his staff throughout these studies, and the financial support provided by the Daniel E. Stuntz Memorial Foundation, Seattle, Washington, and the Department of Botany, University of Washington.

\section{ILLUSTRATIONS}

By P. Brandon Matheny, figures 1-4 (noted above).

\section{LITERATURE CITED}

Matheny, P. B. and B. R. Kropp (2001). A revision of the Inocybe lanuginosa group and allied species in North America. Sydowia 53(1): (in press).

Moser, M. and J. Ammirati. (1999). Studies in North American Cortinarii V. New and interesting Phlegmacia from Wyoming and the Pacific Northwest. Mycotaxon 72:289-321.

Seidl, M. T. (2000) Pylogenetic relationships within Cortinarius subgenus Myxacium, sections Defibulati and Myxacium. Mycologia 92(6):1091-1102. 

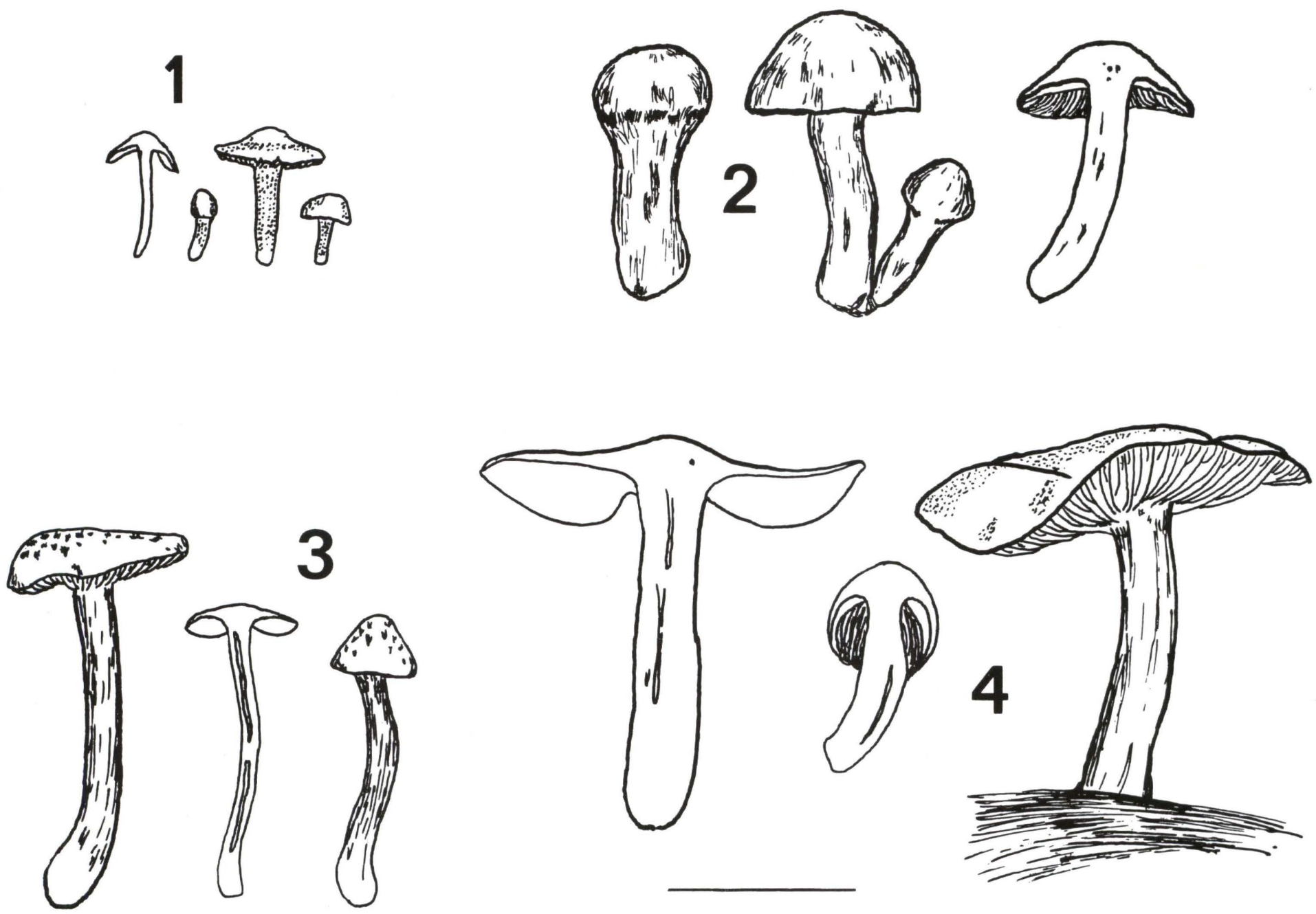

Fig. 1 Inocybe jacobi

Fig. 2 Inocybe leucoblema

Fig. 3 Inocybe mytiliodora

Fig. 4 Inocybe subcarpta 